\title{
Fruit Fall in the Luquillo Experimental Forest, Puerto Rico ${ }^{1}$
}

\author{
Ariel E. Lugo \\ Institute of Tropical Forestry, U.S.D.A. Forest Service, Southern Forest Experiment Station, Call Box 25000, \\ Rio Piedras, Puerto Rico 00928-2500, U.S.A. \\ and \\ Jorge L. Frangi \\ Facultad de Ciencias y Museo, Universidad Nacional de La Plata, Paseo del Bosque, 1900 La Plata, \\ Argentina
}

\begin{abstract}
Fruit fall in the Luquillo Experimental Forest (LEF) varied with forest type but averaged $600 \mathrm{~kg} / \mathrm{ha} / \mathrm{yr}$ for the 11,000 ha forest. Within a given forest type, fruit fall varied spatially and seasonally. A palm (Prestoea montana) flood plain forest averaged $560 \mathrm{~kg} / \mathrm{ha} / \mathrm{yr}$ and individual palm fruit mass changed from season to season. Lower montane wet, or tabonuco (Dacryodes excelsa), forest had a low rate of fruit fall $(332 \mathrm{~kg} / \mathrm{ha} / \mathrm{yr}$ ) and strong seasonal pulses in both space and time. Fruit fall was higher in secondary forests $(820 \mathrm{~kg} / \mathrm{ha} / \mathrm{yr})$ and plantations $(1418 \mathrm{~kg} /$ $\mathrm{ha} / \mathrm{yr}$ ) than in mature tabonuco forests that normally occur in those sites. Fruit fall in the upper montane, or palo colorado (Cyrilla racemiflora), forest averaged $263 \mathrm{~kg} / \mathrm{ha} / \mathrm{yr}$. Somewhere in the LEF there always appears to be a stand at peak rate of fruit production. Fruit fall data are used to reduce a previous estimate of forest carrying capacity for the endangered Puerto Rican parrot, Amazona vittata, from 51,000 to 2000-38,000 birds.
\end{abstract}

\section{RESÚMEN}

La caida de frutos en el Bosque Experimental de Luquillo (BEL) varió con el tipo de rodal pero tuvo como promedio $600 \mathrm{~kg} / \mathrm{ha} /$ año para las 11,000 ha del bosque. En cada tipo de bosque se observaron variaciones estacionales y espaciales en la caída de frutos. La caída de frutos en el bosque de palmeras (Prestoєa montana) en planicies inundables fue de $560 \mathrm{~kg} / \mathrm{ha} /$ año y la masa de frutos individuales varió a través de las estaciones. La caída de frutos en el bosque montano bajo muy húmedo localmente conocido como bosque de tabonuco (Dacrvodes excelsa), fue de 332 $\mathrm{kg} / \mathrm{ha}$ /año y se caracterizó por una estacionalidad marcada en tiempo y espacio. La caída de frutos fue más alta en bosques secundarios $(820 \mathrm{~kg} / \mathrm{ha} /$ año) y plantaciones $(1418 \mathrm{~kg} / \mathrm{ha} / \mathrm{año})$ que en los bosques maduros de tabonuco que normalmente predominan en esos sitios. En el bosque montano de palo colorado (Cyrilla racemiflora) la caída de frutos fue de $263 \mathrm{~kg} / \mathrm{ha} /$ año. Observamos que durante cualquier mes del año algún rodal del BEL exhibe una caída máxima de frutos. Utilizamos la caída de frutos para estimar la capacidad que tiene el bosque para sostener poblaciones de la cotorra puertoriqueña (Amazona vittata), una especie en peligro de extinción. Encontramos que esta capacidad fluctúa entre 2000 y 38,000 animales. Anteriormente se había estimado una capacidad de alimentación para 51,000 cotorras.

Key words: Amazona vittata; Caribbean forests; fruit fall; fruit production; Luquillo Experimental Forest; palm fruits; parrots; phenology; plantations; Puerto Rico; tropical trees.

MANAGEMENT OF TROPICAL FORESTS REQUIRES QUANTITATIVE information of ecosystem processes. Unfortunately, much relevant ecological research fails to influence forest management because results are unavailable to managers, or because its relevance is not obvious. An example is fruit fall data, which are normally collected in ecological studies as part of litterfall measurements, but seldom used for purposes other than budget estimates of nutrients and biomass. Fruit fall data are not presented in Bray

'Received 11 April 1992, revision accepted 26 June 1992. and Gorham's (1964) review of world litter production literature nor in Brown and Lugo's (1982) review of litter production in tropical forests. In fact, most studies of litterfall combine fruits with other miscellaneous components including flowers, bark, or seeds. Yet, fruit fall data is important for understanding geographic variation in reproductive output of tropical trees, and for estimating regenerative potential of these forests after disturbance (Terborgh 1990a). Animal activity is also influenced by fruit fall (Gautier-Hion 1990, Howe 1990).

Our objective is to review available fruit fall data for five forest ecosystems in the Luquillo Ex- 
TABLE 1. Sources of information on fruit fall for the Luquillo Experimental Forest and methods used in the determination of fruit fall rates.

\begin{tabular}{|c|c|c|c|c|}
\hline $\begin{array}{l}\text { Forest type } \\
\text { and time } \\
\text { interval of } \\
\text { study }\end{array}$ & $\begin{array}{c}\text { Area } \\
\text { sampled } \\
\text { (ha) }\end{array}$ & $\begin{array}{c}\text { Number and } \\
\text { area of } \\
\text { baskets } \\
\left(\mathrm{m}^{2}\right)\end{array}$ & $\begin{array}{l}\text { Frequency of } \\
\text { sampling }\end{array}$ & Source \\
\hline \multicolumn{5}{|c|}{ Tabonuco (lower montane) forest } \\
\hline $1964-1966$ & \multicolumn{2}{|c|}{$\begin{array}{l}\text { based on observations } \\
\text { of } 50 \text { palms }\end{array}$} & monthly & Bannister 1970 \\
\hline $1964-1966$ & 2 & $50(0.5)$ & monthly & Wiegert 1970 \\
\hline 1967 & ? & $55-?$ & monthly & Kline et al. 1967 \\
\hline $1980-1981$ & 4 & $80(1.0)$ & bi-weekly & Patterson-Zucca, pers. comm. \\
\hline $1986-1987$ & 10 & $60(1.0)$ & monthly & Devoe 1989 \\
\hline \multicolumn{5}{|l|}{ Secondary forest } \\
\hline $1981-1982$ & 0.8 & $80(0.25)$ & bi-weekly & Lugo 1992 \\
\hline \multicolumn{5}{|l|}{ Plantations } \\
\hline $1981-1982$ & 0.8 & $80(0.25)$ & bi-weekly & Lugo 1992 \\
\hline $1986-1987$ & 0.4 & $60(0.25)$ & bi-weekly & Cuevas and Lugo, pers. comm. \\
\hline \multicolumn{5}{|c|}{ Palo colorado (upper montane) forest } \\
\hline $1981-1982$ & 0.8 & $20(0.25)$ & monthly & Weaver 1987 \\
\hline \multicolumn{5}{|c|}{ Palm flood plain forest } \\
\hline $1980-1981$ & 0.25 & $20(1.0)$ & bi-weekly & This study and Frangi and Lugo 1985 \\
\hline
\end{tabular}

perimental Forest (LEF) as a necessary step to develop a data base useful to forest managers. As an illustration of the potential usefulness of fruit fall data to forest management, we review the estimate of parrot carrying capacity of Snyder et al. (1987).

We take advantage of an extensive data set on fruit fall available for the LEF (Table 1). Measurements began in the 1960s in the Rain Forest Radiation Project (Odum \& Pigeon 1970) and have expanded to several forest types using the same methodology. We focus on three of the four forest environments in the LEF: lower montane (mature, secondary, and plantation stands) tabonuco (Dacryodes excelsa); sierra palm (Prestoea montana synonymous with Euterpe globosa); and palo colorado (Cyrilla racemiflora) forests. Because of high dominance by few species, the forest types of the LEF are usually designated by the common name of the dominant species. These ecosystems are described in detail in Brown et al. (1983). We lack fruit fall information for cloud forests which grow on mountain tops.

\section{METHODS}

The methods consisted of random placement of baskets on the forest floor of each type of forest, periodic collection of material that fell on baskets, separation of material by litter component in the laboratory, drying to constant weight, and weighing.
Because the area of the basket is known as well as the time interval between collections, it is possible to arrive at a quantitative estimate of fruit fall for the whole ecosystem (Table 1). Most fruit production studies count fruits on or below individual trees (e.g., Foster 1990) or estimate fruit abundance qualitatively (e.g., Milton 1991). The method used here provides a quantitative area-based estimate of falling fruits. Our method does not measure fruit production rates because it does not account for fruit consumption prior to fruit fall. The single estimate of sierra palm fruit production that we have for the LEF was 14 times that of the measured fruit fall for the species (Bannister 1970).

The absolute fruit fall of various sectors of the LEF was estimated using stand fruit fall data and information on forest area reported in Brown et al. (1983). Palm flood plain forest fruit fall per unit area data were multiplied by the area of palm brake forest to arrive at an estimate of fruit fall in palm forests. This assumes that trees in the flood plain are as productive as those in the steep slopes that characterize the palm brake. We believe the assumption overestimates fruit fall as flood plains appear to be more productive than palm brakes (Frangi \& Lugo 1985, Lugo \& Rivera Batlle 1987, Lugo et al. in press).

From the outset we had an interest in sierra palm fruits because they are the preferred and sometimes the single food source of the endangered Puer- 
TABLE 2. Sierra palm (Prestoea montana) fruit mass and density data for the Luquillo Experimental Forest. Standard error and number of fruits (in parentheses) are shown.

\begin{tabular}{|c|c|c|c|}
\hline $\begin{array}{l}\text { Forest type } \\
\text { and species }\end{array}$ & Parameter & Value & Source \\
\hline \multicolumn{4}{|l|}{ Palm flood plain } \\
\hline Prestoea montana & $\begin{array}{l}\text { Fruit weight }(\mathrm{g}) \\
\text { Green } \\
\text { All in litter fall } \\
\text { All April-Sept. } 1980 \\
\text { Damaged } \\
\text { Fruit density on ground }\left(\# / \mathrm{m}^{2}\right)\end{array}$ & $\begin{array}{l}1.08 \pm 0.03(37) \\
0.81 \pm 0.03(1706) \\
0.86 \pm 0.05(1632) \\
0.59 \pm 0.04(75) \\
42 \pm 86 \text { (100 plots) }\end{array}$ & $\begin{array}{l}\text { This study } \\
\text { This study } \\
\text { This study } \\
\text { This study } \\
\text { This study }\end{array}$ \\
\hline \multicolumn{4}{|c|}{ Tabonuco (lower montane) forest } \\
\hline Prestoea montana & Fruit weight (g) & $\begin{array}{l}0.07 \text { (seed) } \\
0.59 \text { (seed) } \\
0.52\end{array}$ & $\begin{array}{l}\text { Bannister } 1970 \\
\text { Devoe } 1989 \\
\text { Patterson-Zucca, } \\
\text { pers. comm. }\end{array}$ \\
\hline & Fruit density on ground $\left(\# / \mathrm{m}^{2}\right)$ & $\begin{array}{l}37.7-55 \text { (below palms) } \\
1.41 \text { (whole forest) } \\
0.06-4.3\end{array}$ & $\begin{array}{l}\text { Bannister } 1970 \\
\text { Odum } 1965\end{array}$ \\
\hline
\end{tabular}

to Rican parrot (Amazona vittata or higüaca). Moreover, the sierra palm tree is one of the most abundant tree species in the wet and rain forests of the Caribbean (Lugo et al. 1992). We therefore supplemented the data set with additional measurements on this species using ecosystem-level information. Palm fruits falling on randomly located traps in a flood plain forest were classified according to their appearance (fresh [green] or old [damaged] fruits), counted, dried to constant weight at $60^{\circ} \mathrm{C}$, and weighed individually. In addition, we had access to unpublished information based on monthly observations of 23 sierra palm trees growing in two of the traditional forest feeding sites of the higüaca (Institute of Tropical Forestry files).

We dissected 37 sierra palm fruits to separate the pericarp eaten by parrots (Snyder et al.1987) from the rest of the fruit. This portion was dried and weighed separately. Chemical analysis for this part of the fruit was reported in Snyder et al. (1987). We multiplied mass by nutrient concentration to estimate total nutrient content of the tissue consumed by parrots. To estimate the amount of sierra palm food available to parrots, we multiplied fruit fall by the fraction that was pericarp. This is an underestimate because it ignores the amount of fruit that is eaten before fall but by using flood plain fruit fall data, we may overestimate fruit fall.

Sierra palm fruit fall was also compared with total fruit fall in other forest types in the LEF. For these comparisons we used data in Odum (1965),
Kline et al. (1967), Bannister (1970), Wiegert (1970), Weaver (1987), Weaver and Murphy (1990), Lugo (1992), and unpublished information of Patterson-Zucca, Cuevas and Lugo, and in the files of the Institute of Tropical Forestry (Table 1).

\section{RESULTS}

SIERRA PALM FOREST FRUIT FALL.-Peak fruit fall in flood plain forests during 1980 occurred between May and August (Fig. 1) when 75 percent of the collection baskets $(N=20)$ had palm fruits. In 1981 fruit fall decreased dramatically. The variability of fruit fall was much higher in 1980 than in 1981. The mass of individual palm fruits varied seasonally and also by condition i.e., green fresh fruits $>$ damaged old fruits (Fig. 2a; Table 2). The average mass of individual fruits in the flood plain forest was higher in 1980, a year of high fruit fall, than in 1981, a year of low fruit fall (Fig. 2a). The proportion of green fruits that was available to parrots (the pericarp) was 12 percent; the rest of the fruit is not consumed by the higüaca (Snyder et al. 1987). We don't know if the weight of pericarp changes seasonally or annually.

In the traditional feeding grounds of the higüaca, palm trees had peak values of ripe fruits during February 1987 and December to February in 1988 (Fig. 3). The same pattern was observed in the number of inflorescences bearing fruits per tree. 


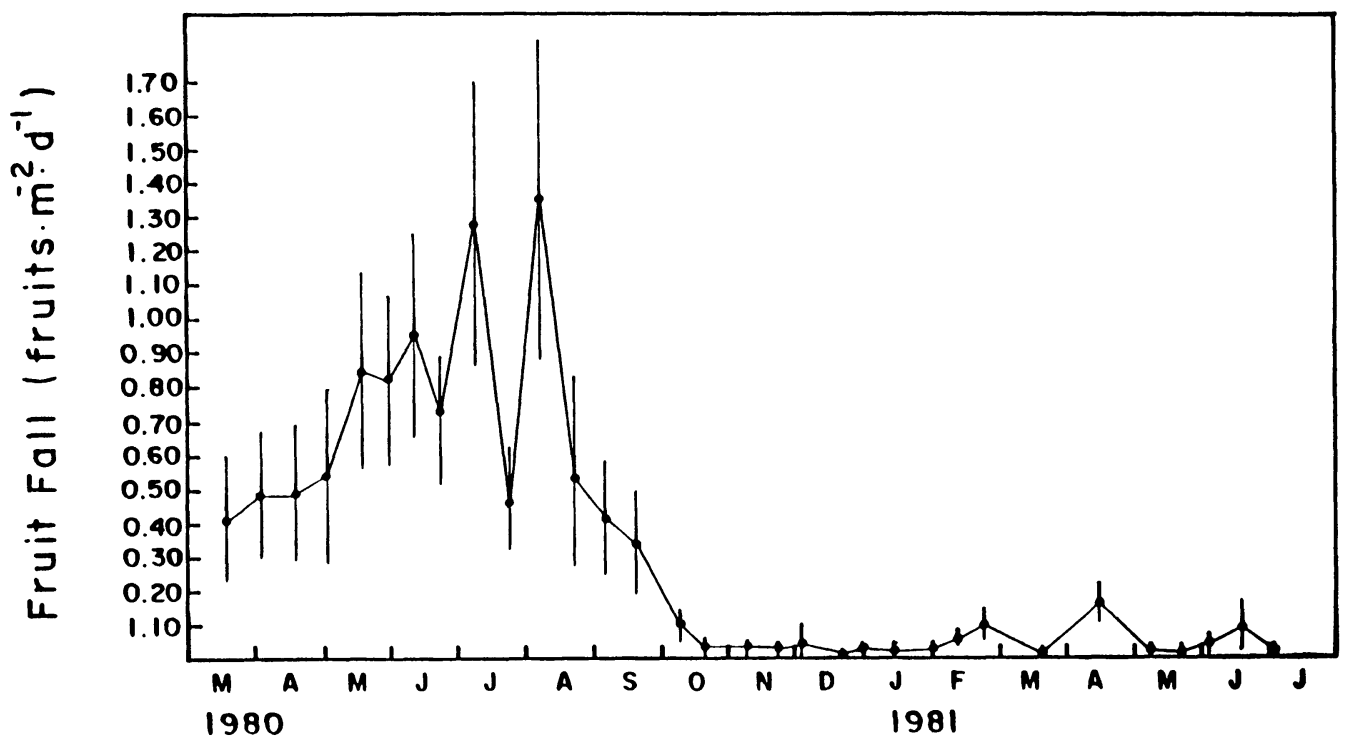

Month

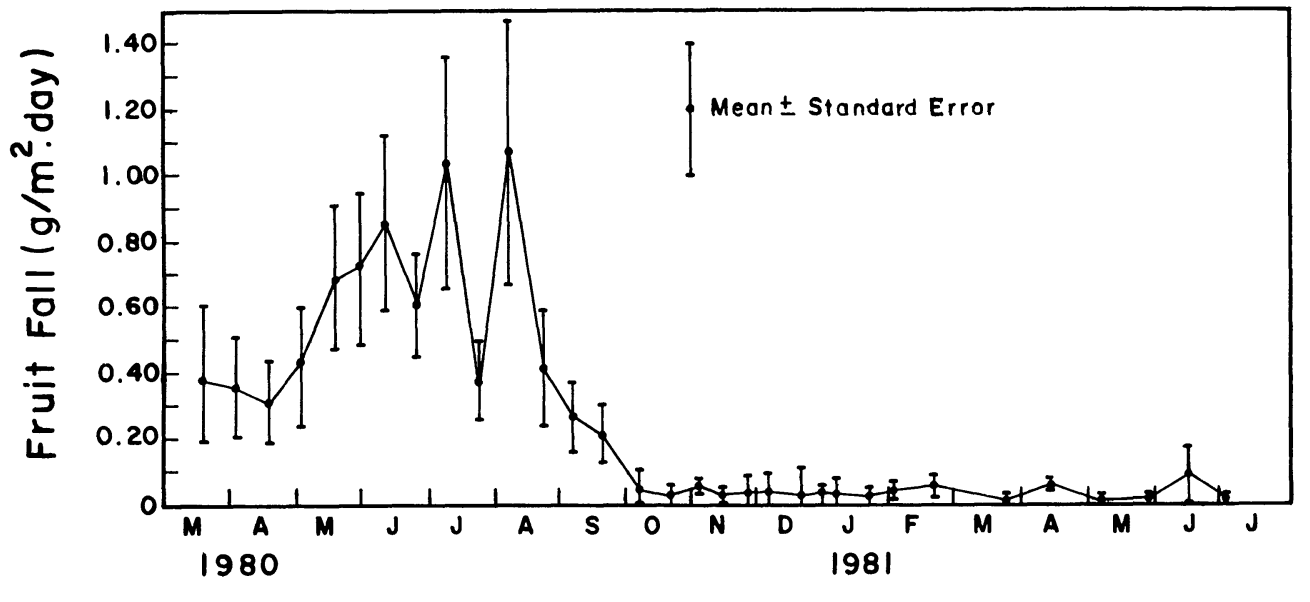

Month

FIGURE 1. Rate of fruit fall in a flood plain forest in the Luquillo Experimental Forest. Fruit fall was measured in (a) number and (b) biomass of Prestoea montana fruits which dominated fruit fall in this forest. Standard error bars are based on 20 values per sampling period.

TABONUCO FOREST FRUIT FALL.-Mature tabonuco forest produced a low but steady supply of fruits year-round, although at anytime different species exhibited pulses of production (Fig. 4; Estrada Pinto 1970, Odum 1970, Devoe 1989, Lugo 1992, C. Patterson-Zucca, pers. comm.). During 1964 to 1966 the forest had a peak of flower production between June and December. Peaks of fruit fall occurred between October and December (Odum 1970). Devoe (1989) reported low fruit fall rates in May and June 1987, and peak rates in July and August 1987. Figure 4 shows peaks of fruit fall in April and October of 1981.

On an annual basis fruit fall in the mature tabonuco forest varied widely from one stand to another (Wiegert 1970, Devoe 1989, C. PattersonZucca, pers. comm.). For example, 1981 fruit fall in four adjacent 1-ha plots studied by PattersonZucca was 207, 24.2, 16.4, and $9.6 \mathrm{~kg} / \mathrm{ha}$. Individual seed mass also changes seasonally in this 

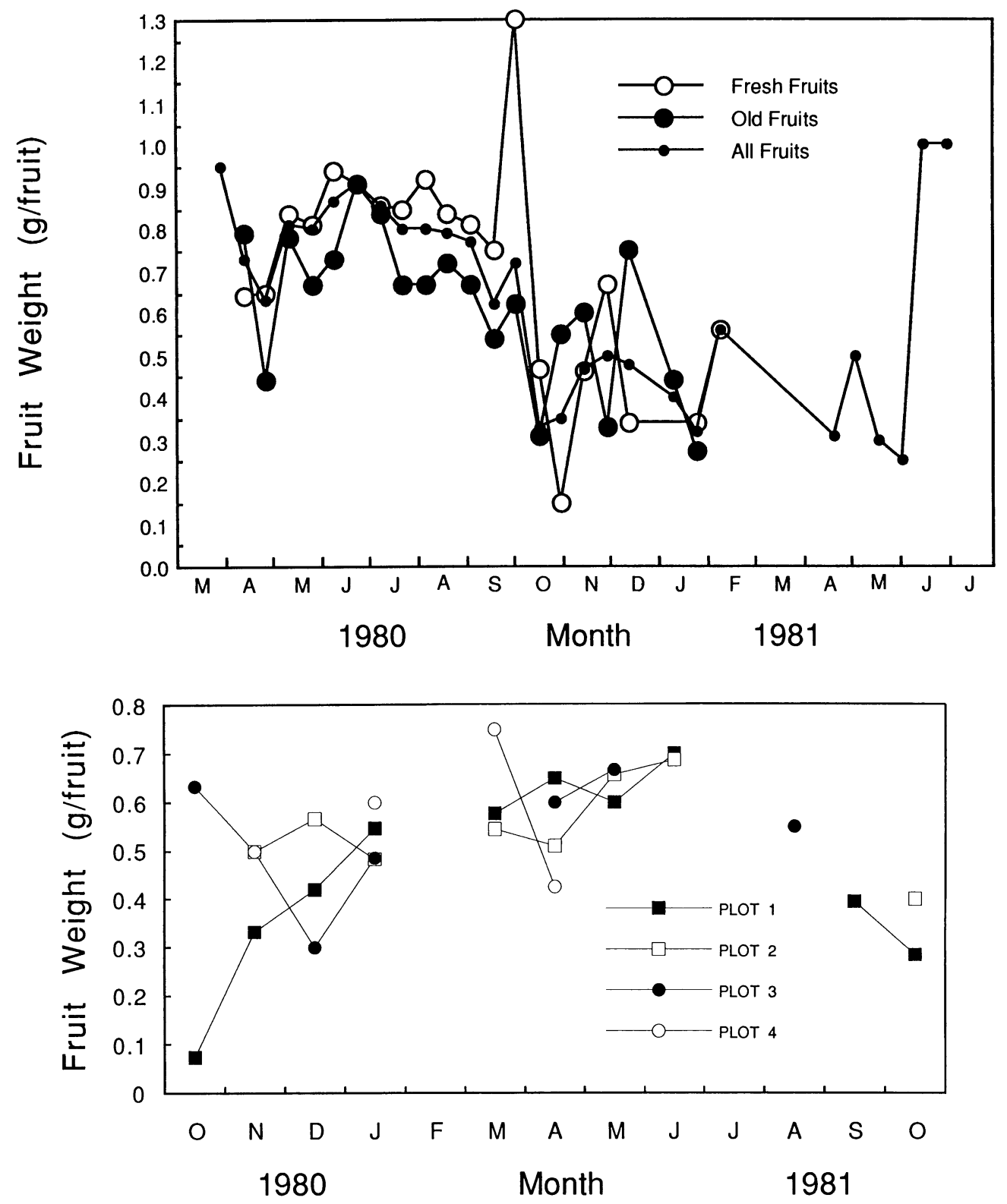

FIGURE 2. Variation in the dry weight of Prestoea montana fruits falling in (a) the flood plain forest, and (b) in tabonuco (Dacryodes excelsa) forest in the Luquillo Experimental Forest. Tabonuco forest data are from C. PattersonZucca (pers. comm.).

forest (Devoe 1989). In addition, fruit fall varied from year to year (Fig. 5).

Bannister (1970) observed sierra palms inside tabonuco forests at peak fruit production in October to February, and at maximum fruit fall between February and April. She observed palms bearing fruit all year long, but more than 50 percent of them had fruits between November and February.
She reported large year to year variation in these patterns.

Sierra palm fruit mass also varied seasonally inside tabonuco forest (Fig. 2b). The average individual fruit mass of sierra palm in tabonuco forest is lower than that in the flood plain forest (Table 2; Fig. 2). The low value reported by Bannister (1970) has not been confirmed by subsequent stud- 


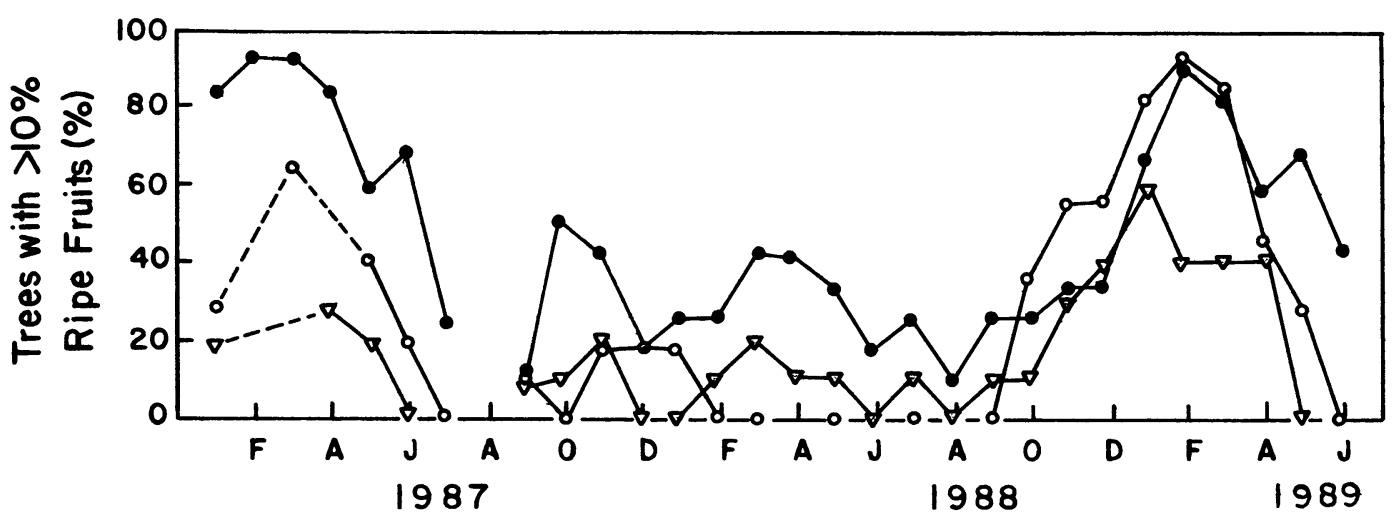

Month

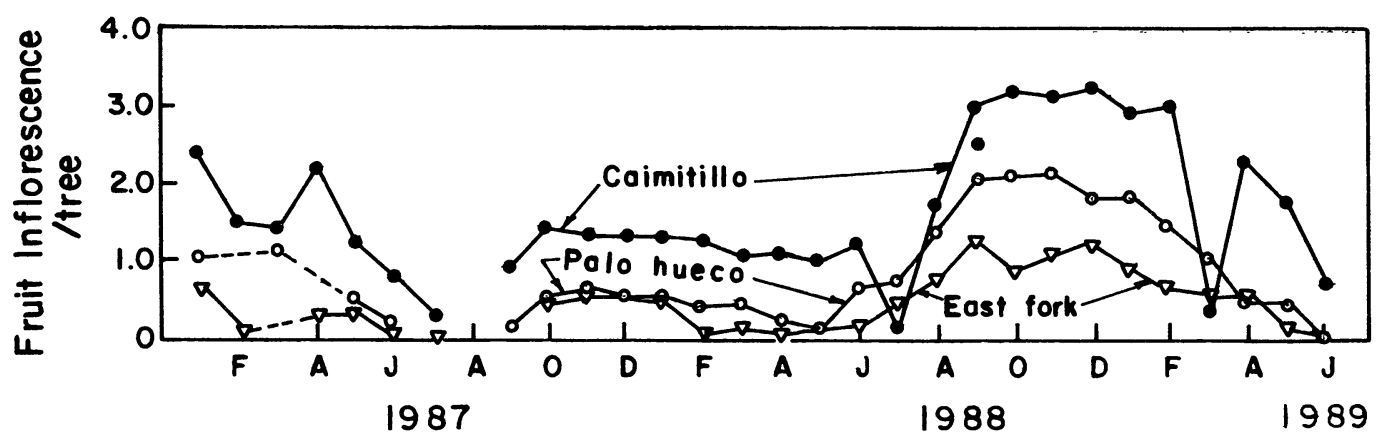

Month

FIGURE 3. Phenology of 23 Prestoea montana trees in the Luquillo Experimental Forest. Trees were growing in a traditional foraging area of the Puerto Rican parrot, Amazona vittata. Data are from the files of the Institute of Tropical Forestry.

ies. Fruit density on the forest floor appears to be a function of distance from source trees (Table 2).

Secondary forests in the tabonuco forest zone ranged widely in annual fruit fall, probably due to age differences and species composition (Lugo 1992; Fig. 5). The seasonal fruit fall variation in these forests was similar to that in mature stands in the sense that peaks and valleys can occur at any time of the year (Fig. 6). This phenological behavior could also be a function of species composition.

Plantation forests growing in the tabonuco forest zone had the broadest range of fruit fall among all forest types in the LEF (Fig. 5). Values ranged from no fruit fall or a low fruit fall in a 4 yr old pine (Pinus caribaea) plantation (Guzmán in Fig. 6 ) and an 18 yr old mahogany (Swietenia macrophylla) plantation (Sabana in Fig. 6) to about 3700 $\mathrm{kg} / \mathrm{ha} / \mathrm{yr}$ in a $26 \mathrm{yr}$ old Eucalyptus patentinervis plantation (Cuevas and Lugo, pers. comm.). An older pine plantation (Cubuy in Fig. 6) had multiple peaks of fruit fall while an old mahogany plantation (El Verde in Fig. 6) had a single, but high, peak of fruit fall during 1981 and 1982. Ten plantation species of the same age, growing adjacent to each other in the LEF arboretum, exhibited different seasonal rates and patterns of fruit fall (Cuevas and Lugo, pers. comm.). For example, five species had periods of peak fruit fall between December and April (P. elliottii, S. macrophylla, P. caribaea, Terminalia ivorensis, and Khaya nyasica). Three species had no marked peaks of fruit fall during the year of study (Hibiscus elatus, E. patentinervis, and $A n$ thocephalus chinensis).

Palo colorado forest fruit fall.- - Fruit fall in the palo colorado forest studied by Weaver (1987) was 276 and $250 \mathrm{~kg} / \mathrm{ha} / \mathrm{yr}$ in 1981 and 1982, respectively. With the exception of certain planta- 


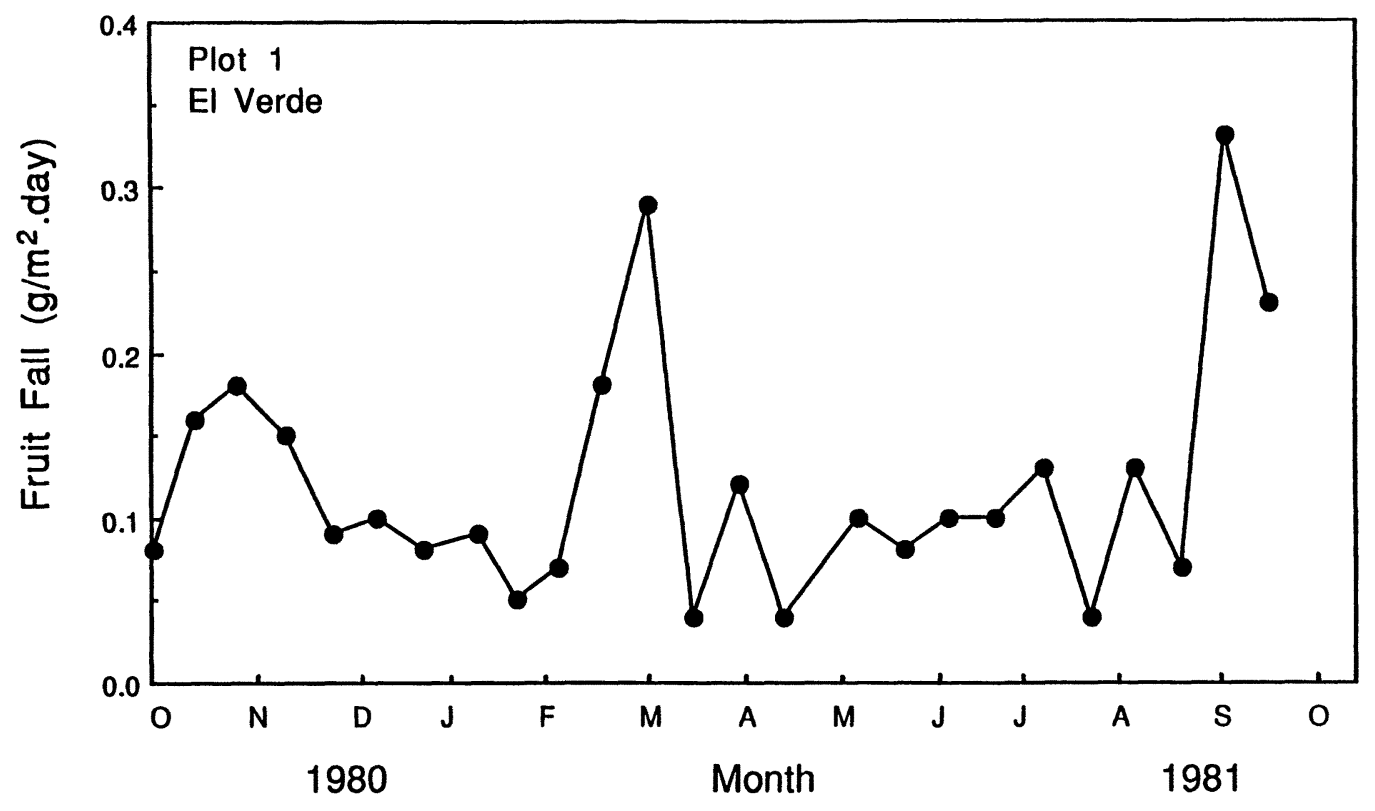

FIGURE 4. Fruit fall in tabonuco (Dacryodes excelsa) forest at El Verde, Luquillo Experimental Forest. These are data from one of four replicate 1 -ha sites studied by C. Patterson-Zucca (pers. comm.). Table 1 summarizes methods used.

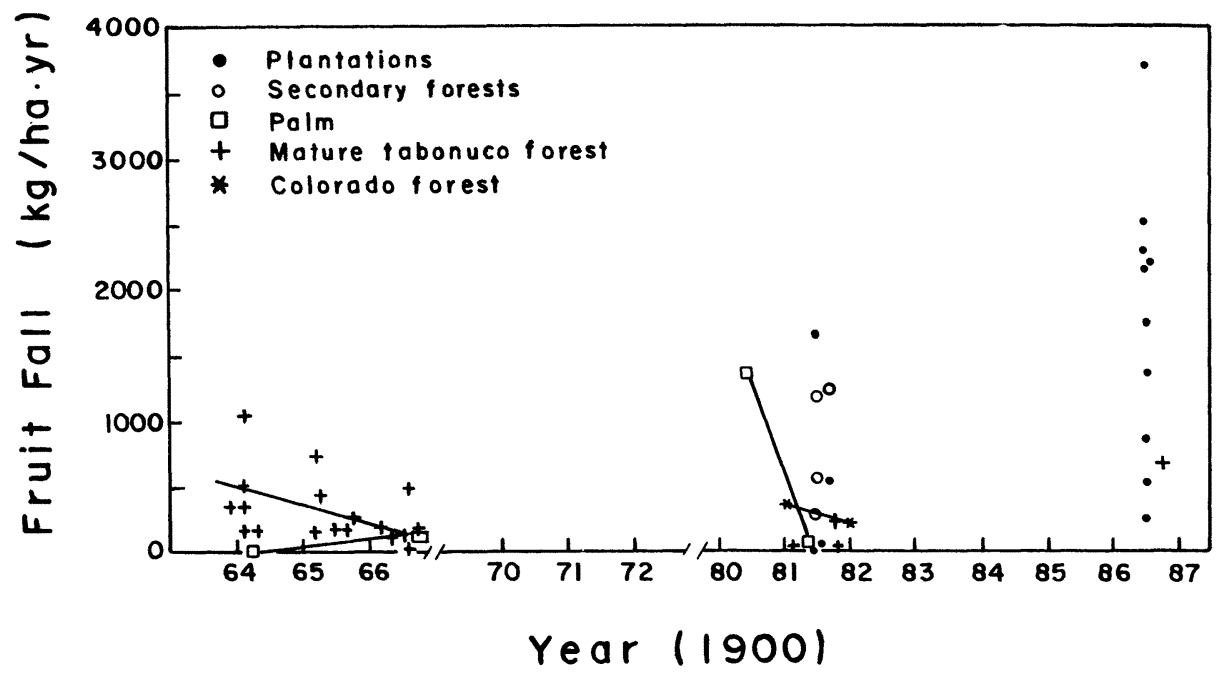

FIGURE 5. Annual rate of fruit fall in several forest types in the Luquillo Experimental Forest. Plantation and secondary forest data for 1981-1982 are from Lugo (1992). Plantation data for 1986-1987 correspond to ten different plantation stands in the Arboretum (Cuevas \& Lugo, pers. comm.). Lugo et al. (1990) describe these plantations and methods are summarized in Table 1. Palm data are from this study, but the 1964, 1967, and 19861987 data were based on information in Bannister (1970), Kline et al. (1967) and Devoe (1989), respectively. These data correspond to palm trees (Prestoea montana). Mature tabonuco forest data are from Wiegert (1970) for the 1964-1967 data, C. Patterson-Zucca (pers. comm.) for 1981 data, and Devoe (1989) for 1986-1987 data. Palo colorado forest data are from Weaver (1987). 

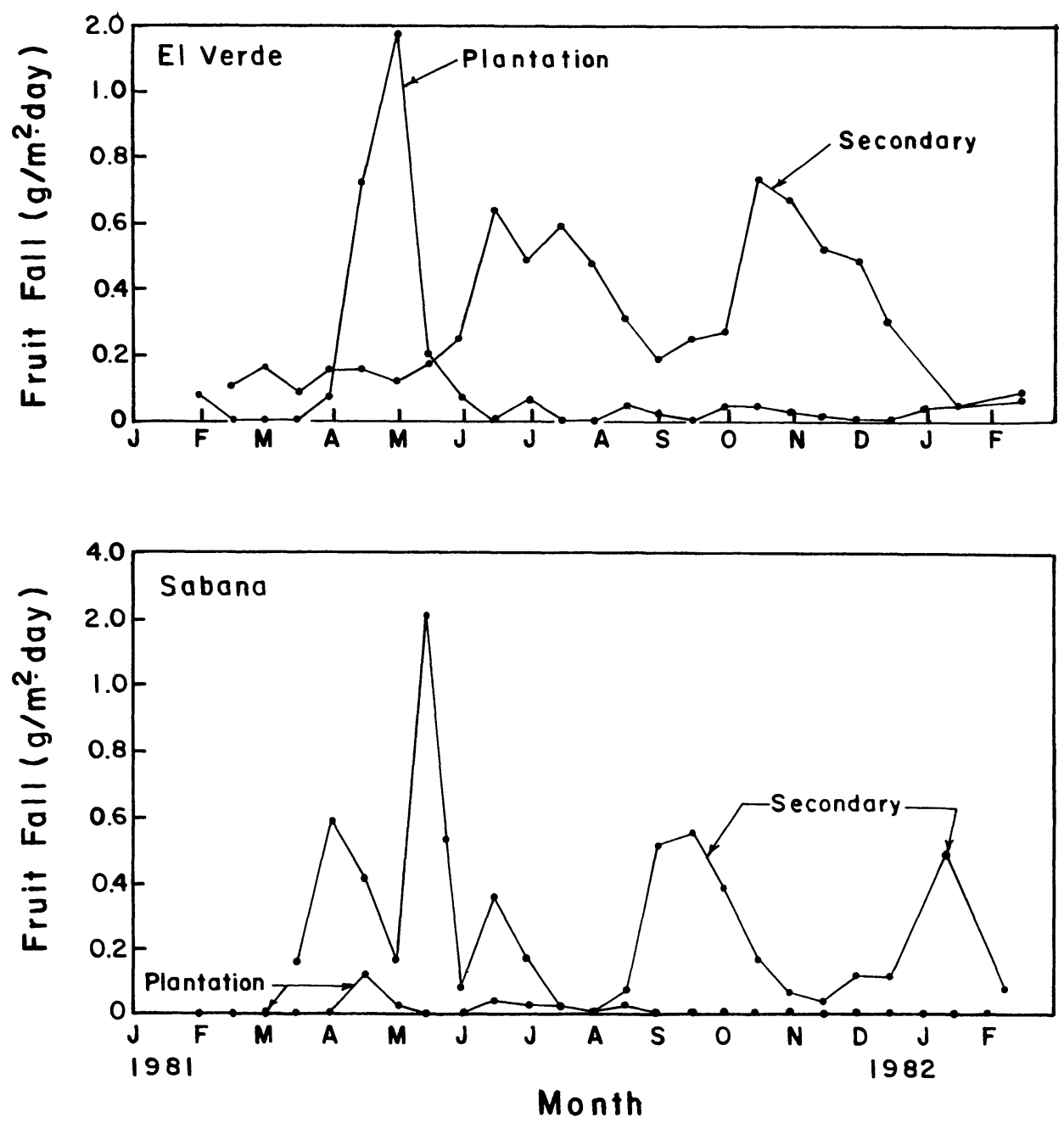

FIGURE 6. Seasonal pattern of fruit fall in plantations and paired secondary forests in the tabonuco forest zone of the Luquillo Experimental Forest. Sites are described in Lugo (1992). Data are from the files of the Institute of Tropical Forestry.

tions, these were the lowest rates observed in the LEF. Weaver reported peak fruit fall between April and August. The pattern occurred two years in a row (1981 and 1982). He reported more wind in stands during periods of peak fruit fall.

\section{DISCUSSION}

Temporal and spatial variation in fruit fall.Results show strong seasonal (Figs. 1, 3, and 6) and annual (Fig. 5) variation in fruit fall in all forest types of the LEF. Similar temporal variation in fruit fall has been described in other tropical forests (Wheelwright 1986, Dunham 1990, Foster 1990,
Terborgh 1990b). When periods of peak fruit fall of all forest types are considered together, there is no month in the year when one of the forest types is not at peak fruit fall. However, sierra palm and secondary forests appear to have the longest periods of peak fruit fall, while plantations and mature tabonuco forests have the shortest. The variation from year to year is evident if one compares fruit fall in tabonuco forests in the 1960s with the 1980s; colorado forest in 1981 and 1982, and sierra palm forest in 1980 with 1981 (Fig. 5).

Fruit production is also variable in space even within the same forest type. This is evident if one compares the phenology of three palm populations 

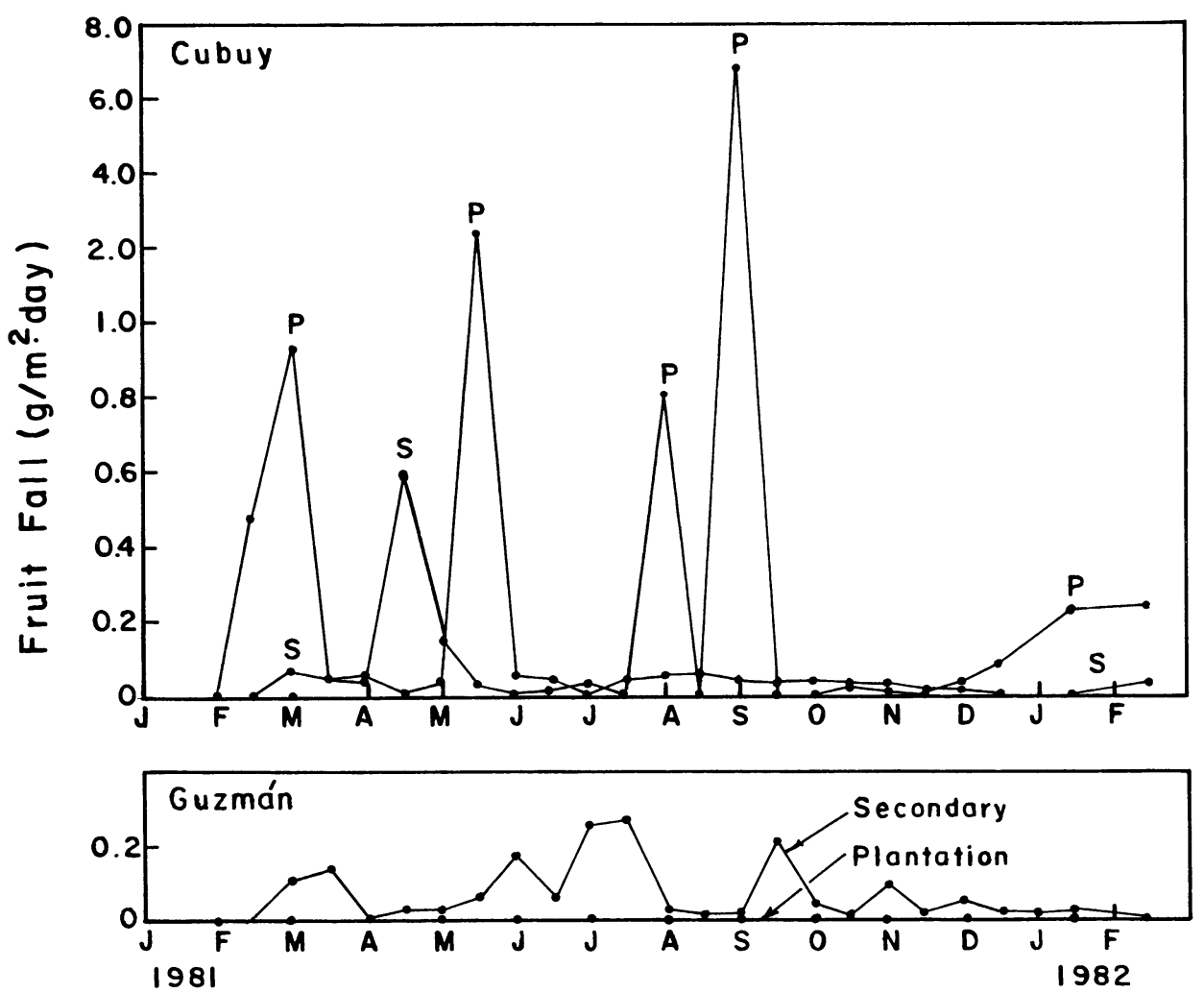

Month

FIGURE 6. Continued.

in the late 1980s (Fig. 3), the fruit fall of mature tabonuco forest in three geographic locations in the 1960s (Wiegert 1970), or the variation of fruit fall for 1986 in plantations inside the arboretum (Fig. 5). Wheelwright (1986), Foster (1990), and Milton (1991) described similar spatial variation in other tropical forests.

VARIATION WITHIN A SPECIES.-The occurrence of the sierra palm in tabonuco and palm flood plain forests allows us to compare the behavior of this species in two contrasting communities. Fruit production by palms, measured in terms of the numbers of fruits that fell (Fig. 1a), was almost a hundred times higher in the flood plain forest in 1980 than in the tabonuco forest in the early 1960s (based on Bannister 1970). If data are expressed in mass units (Figs. 1b, 5), the difference is greater because of differences among individual fruits. Palm fruits in the flood plain forest are heavier than palm fruits in the tabonuco forest (Table 2; Figs. 2a and b, 5). However, in 1981 the flood plain forest produced a similar quantity of palm fruits as did the tabonuco forest. Differences in fruit fall influence the number of fruits on the forest floor (Table 2) i.e., more fruits on the flood plain forest floor than on the tabonuco forest floor, and must also influence the life history of palm populations in these forests.

Estimating total FRUIT FALL. - On a total area basis, most of the fruit fall in the LEF occurs in secondary forests, followed by sierra palm forests (Table 3). Fruit fall among mature forests peaks in the flood plain forest $(750 \mathrm{~m}$ elev.) with lower values at lower (tabonuco) and higher (palo colorado) elevations (Table 3). Secondary forests had higher fruit fall than mature stands within the tatonuco forest type. Moreover, fruit fall increases within certain plantations relative to the tabonuco stand that they replaced (Table 3).

On an average year in the LEF, fruit fall in mature tabonuco forests is relatively low. Sierra palm fruits constitute about 12 percent of the total fruit fall in the LEF. Sierra palm fruit fall is highest in 
TABLE 3. Estimates of palm (Prestoea montana) and total fruit fall by forests in the Luquillo Experimental Forest.

\begin{tabular}{|c|c|c|c|c|c|c|c|c|c|}
\hline \multirow[b]{3}{*}{ Forest type } & \multirow{3}{*}{$\begin{array}{l}\text { Area }^{a} \\
\text { (ha) }\end{array}$} & \multicolumn{4}{|c|}{ Palm fruits } & \multicolumn{4}{|c|}{ All fruits } \\
\hline & & \multirow{2}{*}{$\begin{array}{c}\text { Unit area } \\
\text { mean fall } \\
(\mathrm{kg} / \mathrm{ha} / \\
\mathrm{yr})\end{array}$} & \multicolumn{3}{|c|}{ Total fall $(\mathrm{Mg} / \mathrm{yr})$} & \multirow{2}{*}{$\begin{array}{l}\text { Unit area } \\
\text { mean fall } \\
(\mathrm{kg} / \mathrm{ha} / \\
\mathrm{yr})\end{array}$} & \multicolumn{3}{|c|}{ Total fall $(\mathrm{Mg} / \mathrm{yr})$} \\
\hline & & & Low & Mean & High & & Low & Mean & High \\
\hline \multicolumn{10}{|l|}{ Tabonuco } \\
\hline Mature & 1132 & 35 & 6 & 40 & 118 & 332 & 57 & 376 & 1189 \\
\hline Secondary & 3593 & $86^{\mathrm{b}}$ & 111 & 309 & 467 & 820 & 1056 & 2946 & 4449 \\
\hline Plantations & 378 & 0 & 0 & 0 & & 1418 & 0 & 536 & 1397 \\
\hline Palo colorado & 2083 & 0 & 0 & 0 & & 263 & 520 & 548 & 575 \\
\hline Palm & 2024 & 560 & 146 & 1133 & 2732 & 560 & 146 & 1133 & 2732 \\
\hline Total & 9210 & $161^{c}$ & 263 & 1482 & 3317 & $600^{c}$ & 1779 & 5539 & 10,342 \\
\hline
\end{tabular}

a From Brown et al. (1983); areas are approximate, cloud forest and deforested land not included.

b Used same proportion to total fall as in mature tabonuco forest.

c Area weighted average.

the palm flood plain forest, no matter the unit of measurement (on a unit area or total area basis; Table 3). Within tabonuco forests, sierra palm fruit fall is about 10 percent of the total fruit fall.

Area-weighted fruit fall in the LEF $(600 \mathrm{~kg} /$ ha/yr) is low compared to the values reported by Terborgh $(1986,1990 \mathrm{~b})$ for a Peruvian rain forest at Cocha Cashu ( $\sim 2737 \mathrm{~kg} / \mathrm{ha} / \mathrm{yr})$ or by Singh $e t$ al. (1990) for central Himalayan oak forests at $(2500-3500 \mathrm{~kg} / \mathrm{ha} / \mathrm{yr})$. However, individual stands in the LEF reach the higher values reported elsewhere. Our results are higher than those of Morellato (1992) for subtropical moist altitudinal and semideciduous forests in southeastern Brazil (160 and $400 \mathrm{~kg} / \mathrm{ha} / \mathrm{yr}$, respectively) and those of Dunham (1990) for riverine woodlands in Zimbabwe (7 to $559 \mathrm{~kg} / \mathrm{ha} / \mathrm{yr}$ ).

ReVising the estimate OF SNYDer ET AL. (1987).Fruit production data were considered for the development of a management plan for the endangered Puerto Rican parrot. Snyder et al. (1987) estimated that over 1.5 million sierra palms produced over 7.5 billion fruits per year, or an amount capable of supporting some 51,000 higüacas. This estimate and other analyses of the parrot's natural history supported the assumption that food was not limiting to the bird. As a result, a long-term effort to rescue the species from extinction has focused on nesting sites and reproductive success rather than food availability (Snyder et al. 1987).

The large difference between high and low years of fruit fall greatly affect the food carrying capacity of the forest. Using the same food demand given by Snyder et al. (1987) for the parrot $(87.6 \mathrm{~kg} /$ parrot/yr), and sierra palm fruit fall data in Table 3 , we estimated a carrying capacity of 3000 to 38,000 parrots. The wide range in the estimate reflects the range of fruit fall between high and low years. The calculation uses only one source of food but is based on fruit fall, not production. We don't know the ratio of fruit production to fruit fall in the various forest types and during different seasons. Therefore, our estimate is conservative and much

TABLE 4. Sierra palm (Prestoea montana) food availability ( $\mathrm{kg} / \mathrm{yr}$ ) to the parrot Amazona vittata in the Luquillo Experimental Forest.

\begin{tabular}{lrrrrrr}
\hline $\begin{array}{c}\text { Seasonal } \\
\text { value }^{\mathrm{a}}\end{array}$ & \multicolumn{1}{c}{ Mass $^{\mathrm{b}}$} & Protein $^{\mathrm{c}}$ & \multicolumn{1}{c}{ Fat $^{\mathrm{c}}$} & \multicolumn{1}{c}{ Fiber $^{\mathrm{c}}$} & Ca $^{\mathrm{c}}$ & $\begin{array}{c}\text { Carbo- } \\
\text { hydrates }^{\mathrm{c,d}}\end{array}$ \\
\hline Maximum & 398,040 & 20,379 & 57,676 & 124,228 & 2607 & 153,683 \\
Minimum & 31,560 & 1616 & 4573 & 9850 & 207 & 12,185 \\
Average & 177,840 & 9105 & 25,769 & 55,503 & 1165 & 68,664 \\
\hline
\end{tabular}

a Based on fruit fall data in Table 3.

b $12 \%$ of fruit fall is pericarp.

c Average concentration value from Snyder et al. (1987).

d Water soluble. 
lower than the estimate of 51,000 of Snyder $e t$ al. (1987).

The estimate can be further constrained if carrying capacity is based not on total sierra palm fruit fall but on food available in fruits by multiplying total palm fruit fall by the nutritional quality of pericarp (in Snyder et al. 1987) and the percentage of the fruit (the pericarp) actually consumed by the bird (12\%). With these data (Table 4), the carrying capacity for the higüaca is reduced to an average of about 2000 birds. Even if this value is multiplied by 14 (to account for the difference between fruit production and fruit fall [Bannister 1970]) it results in a low carrying capacity for parrots. The assumption that food was not limiting to parrots when populations were much larger than today may have to be revised and perhaps even the recovery strategy of today's program requires revision because it has not considered food availability per unit area of habitat as potentially limiting to the current population.

\section{ACKNOWLEDGMENTS}

This study was done in collaboration with the University of Puerto Rico. This research was performed under grant BSR-8811764 from the National Science Foundation to the Center for Energy and Environment Research (University of Puerto Rico) and the Institute of 'Tropical Forestry (Southern Forest Experiment Station) as part of the Long-Term Ecological Research Pro ram in the Luquillo Experimental Forest. Additional support was provided by the Forest Service (U.S. Department of Agriculture) and the University of Puerto Rico. We thank S. Brown, $R$. Waide, D. Leahy and an anonymous reviewer for helping us improve the manuscript. We also thank $\mathrm{C}$. Patterson-Zucca, M. Román, and M. Rivera.

\section{LITERATURE CITED}

BAnnister, B. 1970. Ecological life cycle of Euterpe globosa Gaert. In H. T. Odum and R. F. Pigeon (Eds.). A tropical rain forest. National Technical Information Service, Springfield, Virginia.

BRAY, J. R., AND E. Gorham. 1964. Litter production in forests of the world. Adv. Ecol. Res. 2: 101-157.

Brown, S., AND A. E. Lugo. 1982. The storage and production of organic matter in tropical forests and their role in the global carbon cycle. Biotropica 14: 161-187.

, S. SILANDER, AND L. LIEGEL. 1983. Research history and opportunities in the Luquillo Experimental Forest. U.S. Dep. Agric. For. Serv., Southern Forest Experiment Station, General Technical Report SO-44. New Orleans, Louisiana.

Devoe, N. N. 1989. Differential seeding and regeneration in openings and beneath closed canopy in sub-tropical wet forest. Dissertation, Yale University, New Haven, Connecticut.

Dunham, K. M. 1990. Fruit production by Acacia albida trees in Zambesi riverine woodlands. J. Trop. Ecol. 6: 445-457.

Estrada Pinto, A. 1970. Phenological studies of trees at El Verde. In H. T. Odum and R. F. Pigeon (Ed.). A tropical rain forest. National Technical Information Service, Springfield, Virginia.

Foster, R. 1990. Ciclo estacional de caída de frutos en la isla de Barro Colorado. In E. G. Leigh, Jr., A. S. Rand, and D. M. Windsor (Eds.). Ecología de un bosque tropical: ciclos estacionales y cambios a largo plazo, pp. 219-242. Smithsonian Tropical Research Institute, Balboa, Panama.

Frangi, J. L., ANd A. E. Lugo. 1985. Ecosystem dynamics of a subtropical floodplain forest. Ecol. Monogr. 55: 351-369.

Gautier-Hion, A. 1990. Interactions among fruit and vertebrate fruit-eaters in an African tropical rain forest. In K. S. Bawa and M. Hadley (Eds.). Reproductive ecology of tropical forest plants, pp. 219-230. The Parthenon Publishing Group, Park Ridge, New Jersey.

Howe, H. E. 1990. Producción de frutos y actividad animal en dos árboles tropicales. In E. G. Leigh, Jr., A. S. Rand, and D. M. Windsor (Eds.). Ecología de un bosque tropical: ciclos estacionales y cambios a largo plazo, pp. 259-270. Smithsonian Tropical Research Institute, Balboa, Panama.

Kuine, J. R., C. F. Jordan, and G. E. Drewry. 1967. The rain forest project annual report FY-1967. Puerto Rico Nuclear Center, PRNC-103. University of Puerto Rico, Rio Piedras, Puerto Rico.

Lugo, A. E. 1992. Comparison of tropical tree plantations with secondary forests of similar age. Ecol. Monogr. 62: $1-41$.

, AND C. T. Rivera Batlle. 1987. Leaf production, growth rate, and age of the palm Prestoea montana in the Luquillo Experimental Forest, Puerto Rico. J. Trop. Ecol. 3: 151-161.

, A. Bokkestijn, and F. N. Scatena. In press. Structure, succession, and soil chemistry of palm forests in the Luquillo Experimental Forest. In A. E. Lugo and C. Lowe (Eds.). One hundred years of tropical forestry research: results from the first half, themes for the second. Springer-Verlag New York Inc., New York, New York.

, E. Cuevas, and M. J. Sanchez. 1990. Nutrients and mass in litter and top soil of ten tropical tree plantations. Plant Soil 125: 263-280.

Milton, K. 1991. Leaf exchange and fruit production in six neotropical Moraceae species. J. Ecol. 79: 1-26. 
Morellato, L. P. C. 1992. Nutrient cycling in two south-east Brazilian forests. I. Litterfall and litter standing crop. J. Trop. Ecol. 8: 205-215.

Odum, H. T. 1965. The rain forest project annual report FY-65. Puerto Rico Nuclear Center, PRNC 61, page 34, Rio Piedras, Puerto Rico.

1970. Summary, an emerging view of the ecological system at El Verde. In H. T. Odum and R. F. Pigeon (Eds.). A tropical rain forest. National Technical Information Service, Springfield, Virginia.

, AND R. F. PIgEON, Editors. 1970. A tropical rain forest. National Technical Information Service, Springfield, Virginia.

Singh, S. P., Y. S. Rawat, B. S. Rana, and G. C. S. Negi. 1990. Effects of unusually large seed crop on litterfall and nitrogen retranslocation in Himalayan oaks. For. Ecol. Manage. 32: 79-86.

SNYDER, N. F. R., J. W. W ILEY, AND C. B. KePLeR. 1987. The parrots of Luquillo: natural history and conservation of the Puerto Rican parrot. Western Foundation of Vertebrate Zoology, Los Angeles, California.

Terborgh, J. 1986. Community aspects of frugivory in tropical forests. In A. Estrada and T. H. Fleming (Eds.) Frugivores and seed dispersal. Dr. W. Junk, The Hague, Netherlands.

1990a. Seed and fruit dispersal-commentary. In K. S. Bawa and M. Hadley (Eds.). Reproductive ecology of tropical forest plants. The Parthenon Publishing Group, Park Ridge, New Jersey.

1990b. An overview of research at Cocha Cashu biological station. In A. H. Gentry (Eds.). Four neotropical rain forests, pp. 48-59. Yale University Press, New Haven, Connecticut.

Weaver, P. L. 1987. Structure and dynamics in the colorado forest of the Luquillo Mountains of Puerto Rico. Dissertation, Michigan State University, East Lansing, Michigan.

, AND P. G. MURPHY. 1990. Forest structure and productivity in Puerto Rico's Luquillo Mountains. Biotropica 22: 69-82.

WheELWRIGHT, N. T. 1986. A seven-year study of individual variation in fruit production in tropical bird-dispersed tree species in the family Lauraceae. In A. Estrada and T. H. Fleming (Eds.). Frugivores and seed dispersal, pp. 19-35. Dr. W. Junk, The Hague, Netherlands.

WIEGERT, R. G. 1970. Effects of ionizing radiation on leaf fall, decomposition, and the litter microarthropods of montane rain forests. In H. T. Odum and R. F. Pigeon (Eds.). A tropical rain forest. National Technical Information Service, Springfield, Virginia. 